P-ISSN: 2615-1723

E-ISSN: 2615-1766

April 2018
Jurnal Riset Pendidikan Dasar

1 (1), ( 2018) 65-71

Submitted: Februari, Accepted: Maret, Published: April

\title{
PEMBERIAN UMPAN BALIK PADA MODEL PEMBELAJARAN KOOPERATIF TIPE STAD UNTUK MENINGKATKAN HASIL BELAJAR IPA KONSEP PEREDARAN DARAH PADA SISWA SD
}

\author{
Evi Ristiana \\ Prodi Magister Pendidikan Dasar, Pascasarjana Universitas Muhammadiyah Makassar, Indonesia \\ Korespondensi. E-mail: eviristianaunismuh9@gmail.com
}

\begin{abstract}
Abstrak
Penelitian ini merupakan penelitian tindakan kelas (class action research) yang bertujuan untuk meningkatkan hasil belajar melalui pemberian umpan balik pada model pembelajaran kooperatif tipe STAD (Student Team Achievement Division) siswa pada konsep Sistem Peredaran Darah. Subyek penelitian ini adalah siswa Kelas V SD Negeri 1 Mapilli Kabupaten Polewali-Mandar yang terdiri atas dua kelas. Penentuan subyek penelitian dilakukan secara langsung. Penelitian ini dilaksanakan dalam 2 siklus. Data diperoleh dengan menggunakan instrument penelitian yaitu test pilihan ganda yang dilaksanakan setelah empat kali pertemuan. Data dianalisis dengan menggunakan statistik deskriptif dan statistik infernsial dengan uji-t. Dari hasil analisis statistik deskriptif diperoleh nilai rata-rata hasil belajar siswa yang diajar dengan menggunakan model kooperatif STAD dengan umpan balik meningkat pada siklus II dengan nilai rata-rata 7,7 sedangkan pada siklus 1 lebih rendah dengan nilai rata-rata 6,5. Sedangkan hasil analisis statistik infernsial diperoleh nilai $t_{\text {hitung }}=10,91>t_{\text {tabel }}=1,96$. Sehingga disimpulkan ada peningkatan hasil belajar melalui pemberian umpan balik pada model pembelajaran kooperatif tipe STAD siswa.
\end{abstract}

Kata Kunci: Umpan Balik, Kooperatif STAD, Hasil Belajar IPA

\section{GIVING FEEDBACK AT LEAD TYPE COOPERATIVE LEARNING MODEL TO INCREASE LEARNING RESULT OF CONCEPT OF BLOOD CIRCULATION CONCEPT IN STUDENT PRIMARY SCHOOL}

\begin{abstract}
This research is a class action research that aims to improve learning outcomes through the provision of feedback on the model of cooperative learning type STAD (Student Team Achievement Division) students on the concept of Circulatory Systems. The subjects of this study were students of Class V SD Negeri 1 Mapilli Polewali-Mandar Regency consisting of two classes. Determination of research subject is done directly. This study was conducted in 2 cycles. Data were obtained by using research instrument that is multiple choice test which was conducted after four meetings. Data were analyzed by using descriptive statistic and infernal statistic with $t$-test. From the results of descriptive statistical analysis obtained the average value of student learning outcomes are taught by using the STAD cooperative model with feedback increased in cycle II with an average value of 7.7 while in the 1st cycle lower with an average value of 6.5. While the result of statistical analysis infernsial obtained tcount $=10,91>$ ttable $=1,96$. So it is concluded there is an increase in learning outcomes through the provision of feedback on the model of cooperative learning type STAD students.
\end{abstract}

Keywords: Feedback, Cooperative STAD, Learning Outcomes Natural science

Copyright @2018, JRPD, ISSN 2615 - 1723 (Print), ISSN 2615 - 1766 (Online) 


\section{PENDAHULUAN}

Pendidikan sebagai suatu kegiatan yang sistematis dan sistemik terarah kepada terbentuknya kepribadian peserta didik. Pendidikan bermaksud membantu peserta didik untuk menumbuh kembangkan potensipotensi kemanusiannya sehingga terbentuk manusia yang utuh. Dalam hal ini memiliki kesatuan aspek jasmani dan rohani, aspek diri dan aspek sosial, aspek kognitif, afektif dan psikomotorik, serta segi serba keterhubungan manusia dengan dirinya, dengan lingkungan sosial dan alamnya dan dengan Tuhannya.

Pendidikan merupakan bagian integral dalam pembangunan. Pendidikan selalu bertolak dari sejumlah landasan serta mengindahkan sejumlah asas-asas tertentu karena pendidikan merupakan pilar utama terhadap pengembangan manusia dan masyarakat suatu bangsa. Landasan pendidikan akan memberikan pijakan dan arah terhadap pembentukan manusia Indonesia, dan serentak mendukung perkembangan masyarakat, bangsa dan Negara. Sedangkan asas-asas pokok pendidikan akan memberikan corak khusus dalam penyelenggaraan pendidikan itu, dan pada gilirannya memberikan corak pada hasil-hasil pendidikan yakni manusia dan masyarakat Indonesia.

Agenda reformasi saat ini, upaya memperbaiki dan meningkatkan mutu pendidikan seakan tidak pernah berhenti. Beragam program inovatif ikut serta memeriahkan reformasi pendidikan. Reformasi pendidikan adalah restrukturisasi pendidikan, yakni memperbaiki pola hubungan sekolah dengan lingkungannya dan dengan pemerintah, pola pengembangan perencanaan serta pemberdayaan guru dan restrukturisasi model-model pembelajaran. Untuk merealisasikan tujuan tersebut, maka diperlukan suatu upaya yang dapat mendukung tercapainya tujuan pendidikan. Salah satu upaya yang dapat dilakukan adalah dengan memperbaiki sistem pengajaran di dalam kelas, sehingga dibutuhkan kreatifitas sang guru untuk dapat memilih metode yang tepat dalam proses belajar mengajar.

Hubungannya dengan mata pelajaran IPA, guru diharapkan dapat menerapkan konsep-konsep IPA dengan berbagai metode dan media agar proses belajar mengajar IPA dapat berlangsung optimal dan tujuan pembelajaran dapat tercapai dengan baik. Salah satu kreativitas guru yang bisa membangkitkan motivasi belajar siswa adalah dengan memberikan umpan balik terhadap tugas-tugas yang diberikan guru kepada siswa. Menurut Stone dan Nielson dalam Muhammad Ali (1987), balikan mempunyai fungsi untuk membantu siswa dalam memelihara minat dan antusias siswa dalam melaksanakan tugas belajar. Salah satu alasan yang dikemukakan belajar itu ditandai oleh adanya keberhasilan dan kegagalan.

Proses pembelajaran pada hakikatnya merupakan proses interaksi antara subyek didik (siswa) dan obyek (ilmu). Menjadi tanggung-jawab sang guru untuk dapat mengimplementasikan proses tersebut yaitu dengan merancang dan melaksanakan program pembelajaran. Pemilihan metode yang tepat dalam proses belajar mengajar akan dapat membuat siswa lebih terarah dengan sebaik-baiknya serta meningkatkan kemampuan dan prestasi belajar khususnya dalam pembelajaran IPA. Umpan balik merupakan variabel yang sangat penting dalam kegiatan belajar mengajar. Umpan balik memberikan informasi korektif kepada peserta didik. Dengan demikian peserta didik dapat mengetahui tingkat penguasaannya terhadap materi pelajaran. Informasi ini dapat meningkatkan pemahaman peserta didik (Riberu, 1991).

Hasil observasi yang dilakukan pada SD Negeri 1 Mapilli Kabupaten Polewali-Mandar diketahui bahwa guru, pada umumnya menggunakan metode diskusi tanpa umpan balik. Hal ini mengakibatkan motivasi siswa kurang, dimana hanya beberapa orang siswa Copyright (C2018, JRPD, ISSN 2615 - 1723 (Print), ISSN 2615 - 1766 (Online) 


\section{Jurnal Riset Pendidikan Dasar, 1 (1), April 2018 (65-71)}

Evi Ristiana

saja yang antusias, siswa yang lain hanya mencatat dan mendengarkan. Adapun hasil belajar IPA siswa yang diperoleh dari nilai rata-rata siswa yaitu 6,0 sedangkan standar kompetensi adalah 6,5.

Menyadari hal tersebut diperlukan suatu upaya untuk meningkatkan hasil belajar siswa melalui suatu model pembelajaran. Model pembelajaran kooperatif tipe STAD dapat mengembangkan cara belajar siswa untuk dapat belajar secara mandiri dan menjadikan siswa lebih aktif dalam proses pembelajaran. Pemberian umpan balik merupakan suatu rangkaian dari proses belajar mengajar yang diharapkan dapat meningkatkan hasil belajar siswa.

Kaitannya dengan latar belakang pendidikan penulis, maka penelitian ini akan dikaitkan dengan pembelajaran IPA. Salah satu konsep yang dipelajari dalam IPA di Kelas V SD yakni Sistem Peredaran darah. Pengaruh pemberian umpan balik pada model pembelajaran kooperatif STAD dapat dilihat hasilnya melalui hasil belajar IPA Siswa.

Berdasarkan uraian di atas, maka penulis termotivasi melakukan penelitian dengan judul "Peningkatan Hasil Belajar melalui Pemberian Umpan Balik Pada Model Pembelajaran Kooperatif STAD (Student Teams Achievement Division)".

Berdasarkan latar belakang, maka identifikasi masalah dalam penelitian ini dirumuskan: (1) Hasil belajar IPA siswa rendah. (2) Dalam pembelajaran IPA guru kurang menggunakan metode umpan balik. Dan (3) guru masih mendominasi pembelajaran tanpa memberi kesempatan kepada siswa berlatih memecahkan masalah dan memberikan umpan balik.

\section{METODE}

\begin{tabular}{lcrr}
\multicolumn{3}{c}{ Penelitian ini merupakan } & penelitian \\
tindakan kelas dilakukan di & Sekolah \\
Menengah & Pertama Negeri & 1 & Mapilli \\
kabupaten & Polewali-Mandar. & Penentuan \\
tempat & penelitian ini & karena
\end{tabular}
mempertimbangkan peneliti sebagai pengajar disekolah tersebut sehingga mudah untuk mengaplikasikan dan menerapkan metode penelitian.

Subjek penelitian ini ditetapkan siswa Kelas V SD Negeri 1 Mapilli kabupaten Polewali-Mandar yang terdiri atas 60 orang siswa heterogen. Adapun kelas sampel yang diambil secara langsung yaitu kelas 5 A dan 5 $B$ yang memiliki nilai IPA heterogen.

Sumber data atau informasi yang digunakan dalam penelitian ini terdiri dari: Sumber data Primer, yaitu: siswa kelas 5, peneliti. Dan Sumber data sekunder, yaitu meliputi: arsip atau dokumen, tes hasil belajar, lembar observasi.

Teknik pengumpulan data dalam penelitian ini adalah tes sebagai instrument penelitian.

Setelah uji validitas ternyata diperoleh 18 item yang tidak valid, sedangkan 42 item lainnya yang memenuhi syarat diambil tes dan selanjutnya diperiksa tingkat reliabilitasnya dengan rumus Kuder-Richardson 20 (Kr- 20) (Arikunto, 2001).

Data yang terkumpul dalam penelitian ini diolah dengan menggunakan teknik statistik. Teknik statistik yang digunakan yaitu: Analisis statistik deskriptif digunakan untuk mendekripsikan hasil belajar IPA yang diperoleh siswa. Pengelompokkan tersebut dilakukan ke dalam lima kategori, yaitu Sangat tinggi, tinggi, sedang, rendah, dan sangat rendah. Pedoman pengkategorian hasil belajar IPA siswa adalah sebagai berikut:

Tabel 1. Pengkategorian nilai hasil belajar

\begin{tabular}{|c|c|}
\hline Nilai & Kategori \\
\hline $8,1-10,0$ & Sangat Tinggi \\
$6,6-8,0$ & Tinggi \\
$5,6-6,5$ & Sedang \\
$4,1-5,5$ & Rendah \\
$0-4,0$ & Sangat Rendah \\
\hline
\end{tabular}

Sumber: Arikunto (2002)

Berdasarkan pedoman tersebut diatas, maka kriteria yang digunakan untuk Copyright (C2018, JRPD, ISSN 2615 - 1723 (Print), ISSN 2615 - 1766 (Online) 


\section{Jurnal Riset Pendidikan Dasar, 1 (1), April 2018 (65-71)}

Evi Ristiana

menentukan kategori tingkat prestasi belajar adalah dengan menggunakan rumus

Analisis statistik inferensial digunakan untuk membuktikan kebenaran hipotesis penelitian yang telah diajukan. Untuk pengujian hipotesis tersebut, maka analisis dilakukan dengan menggunakan uji-t.

Untuk pengujian hipotesis tersebut, maka analisis dilakukan dengan menggunakan uji-t dengan rumus :

$$
\mathrm{t}=\frac{\mathrm{X}_{1}-\mathrm{X}_{2}}{\mathrm{~s} \sqrt{\mathrm{N}_{1}}+\frac{1}{\mathrm{~N}_{2}}}
$$

Dimana :

$$
\mathrm{S}^{2}=\frac{\left(\mathrm{n}_{1}-1\right) \mathrm{S}_{1}{ }^{2}+\left(\mathrm{n}_{2}-1\right) \mathrm{S}_{2}^{2}}{\mathrm{n}_{1}+\mathrm{n}_{2}-2}
$$

keterangan :

$\mathrm{X}_{1}=$ Rata-rata nilai Siklus II

$\mathrm{X}_{2}=$ Rata-rata nilai Siklus I

$\mathrm{n}_{1}=$ responden Siklus II

$\mathrm{S}_{1} \quad=$ Standar deviasi Siklus II

$\mathrm{n}_{2}=$ responden Siklus I

$\mathrm{S}_{2}=$ Standar deviasi siklus I

Dalam pengujian ini menggunakan asumsi :

$\mathrm{H}_{0}: \mu_{1}=\mu_{2} \quad$ (tidak

perbedaan/peningkatan)

$\mathrm{H}_{1}: \mu_{1} \neq \mu_{2} \quad$ (ada perbedaan/peningkatan)

Dengan demikian $\mathrm{H} 1$ diterima dengan derajat kebebasan (dk) sama dengan $\mathrm{n}_{1}+\mathrm{n}_{2}-$ 2 pada taraf signifikansi $\alpha=0,05$.

\section{HASIL DAN PEMBAHASAN}

Data pada lampiran 3 dan lampiran 5 memperlihatkan bahwa, nilai tertinggi siswa pada siklus I yang mengikuti pembelajaran IPA melalui pemberian umpan balik pada model pembelajaran kooperatif STAD adalah 8,0; nilai terendah 4,0; dan nilai rata-rata 6,5 . Data pada lampiran 4 memperlihatkan bahwa, nilai yang diperoleh siswa pada siklus 2 yang mengikuti pembelajaran IPA melalui pemberian umpan balik pada model pembelajaran kooperatif STAD adalah nilai tertinggi 8,5 ; nilai terendah 6,0 ; dan nilai ratarata 7,7 .

Hasil belajar siswa Kelas V SD Negeri 1 Mapilli diperoleh nilai keseluruhan siswa dari siklus 1 dan siklus 2 nilai hasil belajar yang diperoleh siswa, jika dikelompokkan kedalam lima kategori (Arikunto, 2002), maka distribusi frekuensi dan presentase serta kategori hasil belajar siswa, Kelas V SD Negeri 1 Mapilli yang belajar dengan pemberian umpan halik pada model pembelajaran kooperati 28 menunjukkan rata-rata hasil belajá $a_{1}$ уань meningkat pada saat siklus 2 dengan pemberian umpan balik pada model pembelajaran kooperatif STAD.

60 siswa Kelas V SD Negeri Mapilli yang mengikuti pembelajaran IPA dengan menggunakan umpan balik pada model pembelajaran kooperatif STAD pada dari 60 siswa pada siklus I yang mengikuti pembelajaran dengan umpan balik pada model pembelajaran kooperatif STAD adalah siswa yang memperoleh nilai yang berada pada kategori sangat tinggi; $0 \%$, dikategorikan tinggi; 47,5\% dikategorikan sedang; 35\%, dikategorikan rendah 16,25\% dan 1,25\% siswa dikategorikan sangat rendah. Sedangkan pada siklus II siswa yang memperoleh nilai yang berada pada kategori sangat tinggi; 15\%, dikategorikan tinggi; 75 dikategorikan sedang; $8,75 \%$, dikategorikan rendah $1,25 \%$, dan $0 \%$ siswa dikategorikan sangat rendah.

Hasil analisis data secara inferensial pada taraf kepercayaan $\alpha=0,05$ didapatkan hasil bahwa $t_{\text {hitung }}$ lebih besar dibandingkan dengan $t_{\text {tabel }}$. Nilai $t_{\text {hitung }} 0,97$ sedangkan $t_{\text {tabel( }(0,05)}$ $=1,96$. Jadi ada peningkatan hasil belajar melalui pemberian umpan balik pada model pembelajaran kooperatif tipe STAD.

Hasil analisis data yang telah diuraikan diatas, maka secara deskriptif hasil penelitian ini mengungkapkan bahwa hasil belajar IPA pada siklus I siswa Kelas V SD Negeri 1

Mapilli yang mengikuti pembelajaran dengan Copyright (C2018, JRPD, ISSN 2615 - 1723 (Print), ISSN 2615 - 1766 (Online) 


\section{Jurnal Riset Pendidikan Dasar, 1 (1), April 2018 (65-71)}

Evi Ristiana

pemberian umpan balik pada model pembelajaran kooperatif STAD menunjukkan hasil belajar IPA pada kategori tinggi, presentase siswa yaitu $47,5 \%$ atau sebanyak 38 siswa dari 80 orang siswa pada kelompok kontrol. Pada siklus II menunjukkan hasil belajar termasuk kategori tinggi, hasil penelitian ini didukung oleh besarnya presentase siswa yang mendapat nilai pada kategori tinggi yaitu $75 \%$ atau sebanyak 60 siswa dari 80 orang siswa.

Secara deskriptif hasil penelitian ini juga mengungkapkan bahwa hasil belajar siswa Kelas V SD Negeri 1 Mapilli yang mengikuti pembelajaran dapat dikatakan bahwa "ada peningkatan hasil belajar antara siklus I dan siklus II pada siswa yang diajar dengan pemberian umpan balik pada model pembelajaran kooperatif STAD".

Hasil penelitian ini diperkuat oleh Dahar (1989) yang mengemukakan bahwa: "Para siswa harus memperoleh umpan balik tentang penampilan mereka, yang menunjukkan apakah mereka tahu atau belum mengerti tentang apa yang telah diajarkan. Umpan balik ini dapat memberikan penguatan pada mereka untuk penampilan yang berhasil".

Umpan balik merupakan upaya komunikasi antara siswa dan guru. Guru memberikan penjelasan dan komentar pada pekerjaan siswa dan bersama siswa menelaah kembali jawaban-jawaban soal. Dengan melalui umpan balik siswa mengetahui letak kesalahannya atau bersama dapat memperbaiki proses belajarnya.
Umpan balik secara terbimbing dalam penelitian ini adalah peneliti memberikan tugas kepada siswa, kemudian dengan segera mengoreksi hasil pekerjaan siswa. Hasil pekerjaan siswa diberi komentar atau tanggapan seperlunya pada jawaban yang salah, kemudian dinilai dan segera mengembalikannya kepada siswa. Pada saat itu juga peneliti membahas secara terbimbing tugas yang diberikan baik secara lisan maupun tulisan dan juga memberikan kesempatan kepada siswa untuk bertanya.

Pemberian latihan secara rutin terhadap siswa memberikan balikan akan dapat meningkatkan aktivitas belajar siswa diluar jam pelajaran, karena siswa dapat mempelajari yang telah diperiksa, dan mengetahui letak kesalahannya. Memberi umpan balik pada lembar jawaban siswa memberikan kesempatan kepada siswa untuk memeriksa langkah-langkah yang mereka tempuh dalam menyelesaikan soal, disamping itu mereka mengetahui tingkat penguasaannya terhadap materi. Pada lembar jawaban siswa itu, akan nampak bahwa sebagian siswa dapat menyelesaikan tugas-tugas itu dengan baik sebagaimana yang diharapkan, namun sebagian yang lain sama sekali tidak dapat menjawab soal.

Hasil penelitian ini diperkuat juga dari keterlibatan siswa dalam aktivitas proses belajar (lampiran 10), Penggunaan umpan balik pada model pembelajaran kooperatif STAD meningkatkan keberanian siswa dalam bertanya tentang materi yang belum dipahami. Hal ini diketahui dari persentase sebesar 21,8\% 


\section{Jurnal Riset Pendidikan Dasar, 1 (1), April 2018 (65-71)}

Evi Ristiana

pada siklus II, lebih tinggi dari pada siklus I hanya 17,5\%. Pada kegiatan menjawab pertanyaan yang didiskusikan di kelas persentase siklus II, 25\% lebih tinggi daripada siklus I yang hanya 19,3\%. Kegiatan umpan balik yaitu mengutarakan jawaban atas soal latihan yang diberikan, persentase siklus II $31,8 \%$ dan siklus I 21,8\%. Skor nilai hasil latihan siswa pada setiap pertemuan, siswa yang memperoleh nilai pada kategori tinggi 6,6 - 8,0 pada Siklus II 74\%, sedangkan siklus I 52,5\%. Hasil temuan tersebut mengindikasikan bahwa ada peningkatan aktivitas belajar yang positif pada siswa jika menggunakan umpan balik. Kegiatan berdiskusi lebih banyak dilakukan siswa pada model pembelajaran menggunakan umpan balik, hal ini dapat dilihat pada persentase terdapat sebesar $91,2 \%$ pada siklus II sedangkan pada siklus I 87,5\%.

Siswa yang diajar dengan menggunakan umpan balik pada model pembelajaran kooperatif STAD lebih menampakkan keterlibatannya karena pada metode ini guru memberikan kesempatan pada siswa untuk melakukan latihan singkat tentang pengetahuan yang baru diperolehnya. Hal ini sesuai dengan pendapat Kardi dan Nur (2003), Bahwa dengan adanya pengembangan latihan yang efektif oleh guru maka keterlibatan siswa secara aktif dalam proses belajar mengajar dapat meningkatkan pemahaman dan membuat belajar berlangsung dengan lancar.

Perbedaan hasil belajar ini disebabkan pada pembelajaran yang menggunakan pemberian umpan balik pada model pembelajaran kooperatif tipe STAD membuat siswa lebih aktif dan rasa ingin tahu terhadap materi lebih besar, hal ini juga ditunjang oleh pembelajaran kooperatif STAD yang berorientasi pada siswa. Siswa menjadi lebih aktif dan kreatif terhadap suatu masalah yang dihadapi, kerjasama yang diterapkan menimbulkan motivasi dalam belajar serta menyelesaikan tugas-tugasnya dengan baik. Pemberian pujian dan umpan balik yang dilakukan pengajar pada kinerja yang baik memungkinkan siswa untuk lebih antusias dan bersemangat menerima materi.

Adanya gambaran di atas, menunjukkan bahwa belajar dengan menggunakan umpan balik pada model pembelajaran kooperatif STAD sangat menunjang interaksi belajar siswa. Dimana siswa dapat menemukan sendiri letak kesalahannya dalam menjawab soal dan siswa dapat mengetahui tingkat pemahaman terhadap materi.

\section{SIMPULAN}

Berdasarkan hasil analisis data dan pembahasan hasil penelitian, maka dapat disimpulkan bahwa "Ada peningkatan hasil belajar melalui pemberian umpan balik pada model pembelajaran kooperatif STAD terhadap hasil belajar siswa Kelas V SD Negeri 1 Mapilli Kabupaten Polewali-Mandar konsep Sistem Peredaran Darah".

Berdasarkan kesimpulan hasil penelitian yang telah dikemukakan diatas, maka disarankan, kepada guru mata pelajaran IPA pada umumnya dan yang mengajar di SD Negeri 1 Mapilli Kabupaten Polewali-Mandar pada khususnya. Untuk mempertimbangkan model pembelajaran kooperatif STAD yang disertai umpan balik, karena proses pembelajaran ini dapat membantu guru 


\section{Jurnal Riset Pendidikan Dasar, 1 (1), April 2018 (65-71)}

Evi Ristiana

mendapatkan informasi sejauh mana materi yang diajarkan dipahami oleh siswa. Sehingga guru dapat memperbaiki cara-cara penyampaian informasi lebih baik lagi.

\section{DAFTAR PUSTAKA}

Arikunto, S. (2002). Dasar-dasar Evaluasi Pendidikan (Edisi Revisi). Bumi Aksara. Jakarta.

Arikunto, S. (1997). Prosedur Penelitian. Rineka Cipta. Jakarta.

Dahar, R.W. (1989). Teori-Teori Belajar. Bandung. Tarsito

Djamarah, S.B. \& Zain. (1996). Strategi Belajar Mengajar. Rineka Cipta. Jakarta.

Hardjodipuro, S. (1997). Action Recearch. IKIP Jakarta. Jakarta.

Indana, S. (2003). Pengajaran Langsung. Direktorat Pendikan Lanjutan Pertama. Departemen Pendidikan nasional. Jakarta.

Ibrahim. (2000). Pembelajaran Kooperatif. Pusat Sains UNESA. Univercity Press. Surabaya.

Ibrahim. (2007). Apa yang Dikatakan oleh Peneliti Tentang Kemampuan Soft SKill. Jurnal Matematika MIPA, Ilmu Pengetahuan Alam, dan Pengajaran. Tahun 30. Nomor 1, Agustus. FMIPA Universitas Negeri Malang. Malang.

Jati W. (2007). Aktif IPA untuk SMP Kelas V $S D(K T S P)$. Ganeca exact. Jakarta.

Johnson \& Halubec, E.J. (1993). Cooperation in the Classroom $\left(6^{\text {th }} \mathrm{Ed}\right)$ Diterjemahkan oleh; Edina, MN. Interaction Book Company.

Kardi \& Nur. (2000). Strategi-strategi Pembelajaran. Universitas Negeri Surabaya. Surabaya.

Karmana. (2006). Cerdas Belajar IPA untuk Kelas $V$ SD/MA. Grafindo - Media Pratama.Bandung.

Margono, S. (2004). Metodologi Penelitian Pendidikan. Rineka Cipta. Jakarta

Nur, M. (2000). Pengajaran Berpusat kepada Siswa dan Pendekatan Konstruktivis dalam
Pengajaran. Pusat studi Matematika dan IPA Sekolah. Universitas Negeri Surabaya. Surabaya.

Riberu. (1991). Mengajar dengan Sukses. Rineka Cipta. Jakarta.

Roestiyah, N. K. (1991). Strategi Belajar Mengajar. Rineka Cipta. Jakarta.

Syamsiah. (1999). Efektitivitas Pemberian Tes Tanya Jawab pada Setiap Akhir Pertemuan Terhadap Pencapaian Hasil Belajar Fisika Siswa SMU Negeri 13. Skripsi.FMIPA IKIP Ujung Pandang.

Silberman Mel. (1996). Active Learning : 101 Strategies to teach Any subject. Penerjemah H. Sardjuli dkk. Ally \& Bacon, A Simon \& Schuster Company. Needham Heights.- Massachussets. USA.

Slameto. (1995). Belajar dan Faktor-faktor yang Mempengaruhinya. Rineka Cipta. Jakarta.

Sujadi, A. (1997). Membuat Siswa Aktif Belajar. Mandar Maju. Bandung.

Sudjana. (1996). Metode Statistika. Tarsito. Bandung.

Copyright $\odot 2018$, JRPD, ISSN 2615 - 1723 (Print), ISSN 2615 - 1766 (Online) 